\title{
Pulse Production, Consumption and Utilization in Nigeria within Regional and Global Context
}

\author{
Nkechi P. Akah ${ }^{1}$, Catherine N. Kunyanga ${ }^{1}$, Michael W. Okoth ${ }^{1} \&$ Lucy G. Njue ${ }^{1}$ \\ ${ }^{1}$ Department of Food Science, Nutrition and Technology, University of Nairobi, Kenya \\ Correspondence: Nkechi P. Akah, Department of Food Science, Nutrition and Technology, Faculty of Agriculture \\ and Veterinary Sciences, University of Nairobi, P. O. Box 29053-00625, Kangemi, Nairobi, Kenya. Tel: \\ 254-791-484-068. E-mail: nkechi.akah@unn.edu.ng
}

Received: October 21, 2020 Accepted: March 2, 2021 Online Published: March 14, 2021

doi:10.5539/sar.v10n2p48 URL: https://doi.org/10.5539/sar.v10n2p48

\begin{abstract}
Malnutrition, hunger, and poverty are still major challenges globally especially in Sub-Saharan Africa affecting most countries like Nigeria. Legumes play key roles in food and nutritional security, health, and income generation. This review highlights status of pulse production and consumption in Nigeria and need for improvement. The study involved in-depth desk review. Data sources include FAO Statistics and other publication sources. Cowpea is Nigeria's major pulse accounting for $95.45 \%$ area and $97.55 \%$ of the pulse production in 2016-18. Nigeria is the leading global cowpea producer with 39\% production in 2016-18. However, the cowpea area has been declining, with 30\% loss at 3.5\% yearly between 2006-08 and 2016-18. The production appreciated by $40 \%$ viewed from 1996-98 due to increase in yield; but, overall, Nigeria's cowpea production is marked with fluctuations/stagnation. It, thus, imports to meet domestic demand. In contrast, cowpea area, yield and production received steady and remarkable positive growth in places like Niger $(73 \%$ at $2.8 \%, 213 \%$ at $5.9 \%$, and $428 \%$ at $8.7 \%$ annually, respectively). Per capita availability of pulses in Nigeria is over 10 times less than cereals' and roots/tubers'; hence, pulses contribute poorly to daily calorie and protein intakes. They are mainly utilized as cooked bean and steamed/fried pastes. Low pulse consumption is seriously contributing to nutritional problems in developing countries like Nigeria. Diverse utilization, optimizing nutritional quality of the traditional dishes, and improving safety and acceptability of especially those sold as street food can enhance their consumption, production and contribution to nutritional security.
\end{abstract}

Keywords: consumption, food and nutritional security, Nigeria, productivity, pulses

\section{Introduction}

Nigeria is highly populated (160 million people) (Gerland et al., 2014) and burdened by serious level of hunger with 29.2 score on 2020 Global Hunger Index severity scale ( $\leq 9.9$ [low], 10-19.9 [moderate], 20-34.9 [serious], $35-49.9$ [alarming] and $\geq 50$ [extremely alarming]) which is probably worse if impact of COVID-19 pandemic among other crises sure to have escalated hunger situations in many countries is reflected (von Grebmer et al., 2020). Food insecurity and extreme poverty plague 50-over 60\% of Nigerians (Okuneye, 2002; Oriola, 2009; Ojo \& Adebayo, 2012). A survey of the Igbo area showed that low energy intakes due to insufficient food consumption were high among household members including adults and children (Okeke et al., 2009). Malnutrition afflicts 38\% and causes over 50\% of all maternal, new born and child deaths, with $40 \%$ of children under 5 stunted and 25\% wasted (The Food and Agriculture Organization of the United Nations [FAO], 2012; Ojo \& Adebayo, 2012; Ene-Obong et al., 2013; FAO, 2017). Vitamin A, calcium, iron, zinc, niacin and riboflavin deficiencies were most prevalent among the study group in Igbo area with higher incidence in children aged 6-12 years (Okeke et al., 2009). The situations are mainly attributed to decline in agricultural productivity, monotonous diets of starchy staples and/or dietary shifts to exotic high caloric foods. Boost in agricultural productivity and diversification in food production and diets to include nutrient-rich foods like legumes are some key strategies to assuage food insecurity, poverty, and nutritional problems in Nigeria and other developing countries (Okuneye, 2002; Okeke, Eneobong, Uzuegbunam, Ozioko, \& Kuhnlein, 2008; Okeke et al., 2009; FAO, 2012; Diao, Hazell, \& Thurlow, 2010; Wilhelmina, Joost, George, \& Guido, 2010; Lawal, 2011; Ene-Obong et al., 2013; FAO, 2016; FAO, 2017; International Food Policy Research Institute [IFPRI], 2017; Ayenew, Biadgilign, Schickramm, Abate-Kassa, \& Sauer, 2018). 
Legumes are the second most important food to man after cereals. In Nigeria, they are produced and consumed after cereals and roots/tubers (Okeke et al., 2008; Ene-Obong et al., 2013). They are cheap and key sources of protein, calorie, B-vitamins, minerals, and dietary fiber especially for people subsisting mainly on plant foods. They are low in fat, contain no cholesterol but have cholesterol lowering effect, and regulate blood glucose due to low glycemic index. Optimal combination of legumes and cereals produce protein quality similar to animal protein. They, thus, play critical roles in food and nutrition security and healthy living (FAO, 2016). They are grouped as oilseeds and pulses mainly used as food. Pulses of global importance (in terms of area and production) include dry bean, cowpea, chickpea, dry peas, lentils, pigeon pea and broad beans (FAO, 2016; http://faostat.fao.org).

Nigeria plays significant role in global pulse production being among top ten (FAO, 2016) and the leading producer and consumer of cowpea (Vigna unguiculata), also its major legume locally in production, consumption, research, policy and trade (Langyintuo et al., 2003; Timko, Ehlers, \& Roberts, 2007; http://faostat.fao.org/). However, several minor pulses are grown like Bambara groundnut, pigeon pea and African yam bean which are also important food security and economic crop in many of the localities (Okeke et al., 2008; Ene-Obong et al., 2013).

Nigeria's status as leading cowpea producer, notwithstanding, it imports to meet domestic demand due to production deficit. Although the yield significantly improved in Nigeria, it is incomparable to yields in developed nations and not enough to compensate for decline in the area and the increasing population. This is applicable to other parts of Africa where pulses' importation to meet local demand is common (FAO, 2017). Pulse per capita availability and supply of daily calorie and protein intakes in Nigeria and globally is also poor (http://faostat.fao.org/).

Pulses are eaten mainly as cooked bean in Nigeria and other parts globally, and also majorly as pudding/bean cakes popular all over Western Africa especially cowpeas' (KIu, Amoatey, Bansa, \& Kumaga, 2001; Madukwe \& Ene-Obong, 2002; Langyintuoa et al., 2003; Wilhelmina et al., 2010; Ene-Obong et al., 2013; FAO, 2016; Nnamani et al., 2017). The dishes especially pudding are readily available as street/fast food and, so, play critical nutritional and economic roles in many places particularly Nigeria (Wilhelmina et al., 2010; Oranusi \& Braide, 2012; Steyn et al., 2013; Afolabi, Towobola, Oguntona, \& Olayiwola, 2013; FAO, 2016; The Organization for Economic Co-operation and Development [OECD]/FAO, 2016; Hongbété, Tidjani, \& Kindossi, 2017; IFPRI, 2017).

Pulses have enormous potentials of improving nutritional security in Nigeria and other places in Africa and beyond. Their low production and especially consumption is contributing majorly to the prevalent malnutrition and rising incidence of chronic ill health like diabetes in Nigeria and other parts globally where people subsist mainly on starchy staples (Ene-Obong et al., 2013; Udenta, Obizoba, \& Oguntibeju, 2014; IFPRI, 2017). This report highlights production and consumption status of cowpea and other pulses in Nigeria and need to improve their productivity and consumption/utilization. It also emphasizes the need to improve nutritional quality, safety and/or acceptability of the local pulse products especially those sold as street food in addition to incorporating pulses/their flours into other local staples as a key strategy to improving their consumption and assuaging the prevalent nutritional problems. In addition, information provided will promote trade as it identifies surplus and deficit countries/regions especially for cowpea. It is hoped that this report will be useful to stakeholders including producers, consumers, researchers, nutritionists and policy makers.

\section{Methodology and Limitations in the Study}

Articles were searched in Google Scholar using terms including "global/world, regional/region, Sub-Saharan Africa, Nigeria, together with pulses, production, consumption, utilization, constraints", or "Nigeria, together with food/nutritional security/poverty status; factors affecting food security; strategies to mitigating poverty/food insecurity/malnutrition" as keywords. Refereed journal articles were focused on; however, relevant non-journal writings like technical reports and other "gray/grey" literature, and book/book chapters were included. Articles written in English only were used; incomplete articles were discarded. Food and Agricultural Organization Statistical database (FAOSTAT) (http://faostat.fao.org) served as main sources for production and consumption data (the accuracy, therefore, largely depend on FAOSTAT). Data were also gathered from analysis and survey reports and other publication sources. Observation/practice and interviews/focus group discussions were additional information sources for bean utilization in Nigeria; the outcome is woven into the report. All the production data presented are a 3-year average from 1996 to 2018. However, yield and production of pulses can vary sharply from year to year which may not be captured. Per capita availability/consumption was calculated from FAOSTAT food balance sheets on "food supply quantity" (kg/capita/year); 2010-13 averages were used. 
Percentage contribution to daily calorie/protein intakes was calculated using data on "food supply" (kcal/capita/day)/“protein supply quantity" (g/capita/day) and mean calorie/protein requirements for healthy adults. Data focused on cowpea and pulses, nes (pulses undifferentiated individually in FAOSTAT due to limited international and/or local importance) under which minor pulses in Nigeria are categorized.

Increase/growth in area, yield or production was estimated using logarithmic estimation method on Excel worksheet:

$$
\text { Growth }(\%)=(\text { LOGEST }(\mathrm{Y} 1: \mathrm{Yn})-1) * 100
$$

The average annual growth rate was calculated on Excel spreadsheet using the formula:

$$
\text { Growth rate }(\%)=\left((\mathrm{Yn} / \mathrm{Y} 1)^{\wedge}(1 / \mathrm{t})-1\right)^{*} 100
$$

$\mathrm{Y} 1$ and $\mathrm{Yn}$ are the first and last year data for each variable considered; $\mathrm{t}=$ time period from $\mathrm{Y} 1$ to $\mathrm{Yn}$

\section{Results and Discussion}

\subsection{Production of Cowpea in Nigeria Relative to Global and Regional Production}

Nigeria is among top ten pulse producers globally and with Ethiopia the largest in Africa, the second major producing region after Southern Asia. India is the leading producer; others include Canada, Myanmar, China, Brazil, Australia, United States of America (USA), and Russian Federation. Nigeria accounted for 3.5\% global area and $3.1 \%$ production of pulses in 2016-18, India for 37\% area and 25\% production, and the 10 major countries for $65.8 \%$ production (Table 1) (FAO, 2016; http://faostat.fao.org). 
Table 1. Pulse production by region/top countries (2016-18 averages)

\begin{tabular}{|c|c|c|c|c|c|}
\hline Region/country & $\begin{array}{l}\text { Area harvested } \\
\text { ('000 ha) }\end{array}$ & $\begin{array}{l}\text { *Area } \\
(\%)\end{array}$ & $\begin{array}{l}\text { Production } \\
(\cdot 000 \text { t) }\end{array}$ & $\begin{array}{l}\text { *Production } \\
(\%)\end{array}$ & $\begin{array}{l}\text { Yield } \\
\text { (kg/ha) }\end{array}$ \\
\hline World & 92329 & - & 89857 & - & 973 \\
\hline Asia & 46868 & 50.76 & 39264 & 43.70 & 836 \\
\hline Central Asia & 848 & 0.92 & 1055 & 1.17 & 1302 \\
\hline Eastern Asia & 3106 & 3.36 & 5250 & 5.84 & 1690 \\
\hline Southern Asia & 36963 & 40.03 & 24318 & 27.06 & 655 \\
\hline Southeastern Asia & 4820 & 5.22 & 7081 & 7.88 & 1470 \\
\hline Western Asia & 1132 & 1.23 & 1560 & 1.74 & 1380 \\
\hline Africa & 25340 & 27.44 & 19212 & 21.38 & 758 \\
\hline Northern Africa & 1109 & 1.20 & 1108 & 1.23 & 998 \\
\hline Eastern Africa & 9339 & 10.11 & 9335 & 10.39 & 999 \\
\hline Middle Africa & 2428 & 2.63 & 1546 & 1.72 & 637 \\
\hline Southern Africa & 124 & 0.13 & 107 & 0.12 & 856 \\
\hline Western Africa & 12339 & 13.36 & 7116 & 7.92 & 577 \\
\hline Northern America & 5431 & 5.88 & 10513 & 11.70 & 1934 \\
\hline Central America & 2591 & 2.81 & 2284 & 2.54 & 881 \\
\hline Caribbean & 513 & 0.56 & 457 & 0.51 & 890 \\
\hline South America & 3979 & 4.31 & 4222 & 4.70 & 1060 \\
\hline Europe & 5298 & 5.74 & 10773 & 11.99 & 2046 \\
\hline Eastern Europe & 3334 & 3.61 & 6127 & 6.82 & 1862 \\
\hline Northern Europe & 730 & 0.79 & 2148 & 2.39 & 2917 \\
\hline Southern Europe & 720 & 0.78 & 1025 & 1.14 & 1431 \\
\hline Western Europe & 513 & 0.56 & 1472 & 1.64 & 2861 \\
\hline Oceania & 2309 & 2.50 & 3133 & 3.49 & 1356 \\
\hline Australia \& New Zealand & 2296 & 2.45 & 3121 & 3.47 & 1359 \\
\hline India & 34143 & 36.98 & 22337 & 24.86 & 651 \\
\hline Canada & 3637 & 3.94 & 7254 & 8.07 & 1991 \\
\hline Myanmar & 3955 & 4.28 & 6197 & 6.90 & 1568 \\
\hline China & 2694 & 2.92 & 4857 & 5.41 & 1802 \\
\hline Russian Federation & 2146 & 2.32 & 3546 & 3.95 & 1687 \\
\hline USA & 1794 & 1.94 & 3258 & 3.63 & 1827 \\
\hline Australia & 2288 & 2.48 & 3099 & 3.45 & 1353 \\
\hline Ethiopia & 1583 & 1.71 & 2903 & 3.23 & 1833 \\
\hline Brazil & 2769 & 3.00 & 2872 & 3.20 & 1037 \\
\hline Nigeria & 3228 & 3.50 & 2775 & 3.09 & 863 \\
\hline Niger & 5801 & 6.28 & 2182 & 2.43 & 377 \\
\hline Tanzania & 2085 & 2.26 & 2008 & 2.23 & 963 \\
\hline Mexico & 1758 & 1.90 & 1526 & 1.70 & 867 \\
\hline Turkey & 833 & 0.90 & 1203 & 1.34 & 1449 \\
\hline Kenya & 1843 & 2.00 & 1142 & 1.27 & 620 \\
\hline Uganda & 746 & 0.81 & 1069 & 1.19 & 1433 \\
\hline United Kingdom & 312 & 0.34 & 1036 & 1.15 & 3301 \\
\hline Ukraine & 460 & 0.50 & 1023 & 1.14 & 2304 \\
\hline France & 323 & 0.35 & 905 & 1.01 & 2797 \\
\hline Malawi & 766 & 0.83 & 707 & 0.79 & 929 \\
\hline Burkina Faso & 1302 & 1.41 & 665 & 0.74 & 511 \\
\hline
\end{tabular}

Source: http://faostat.fao.org/ *Percent share of respective regions/countries in global pulses' area and production. Regional grouping/aggregation of countries is according to United Nations Statistical Division (UNSD, 2006).

Nigeria's pulse production centers on cowpea and so is its contribution to global pulses' production. It is the leading producer with 3.1 million ha and 2.7 million $t$ in 2016-2018 representing $25 \%$ global area and 39\% production, and $29 \%$ and $46.3 \%$, respectively in Western Africa the key region (86 and 83\%, respectively) (Table 2). Niger is the second major producer (46\% area and 30\% production) and Burkina Faso, third (10 and 8.5\%, 
respectively), with significant production also in Eastern (7.3 and 7.2\%, respectively), Middle Africa (3 and $3.7 \%$, respectively), and Myanmar (1.1 and 2\%, respectively) (Table 2). Brazil and India are considered major producers globally (top five); however, they are not included in FAO cowpea data (Timko et al., 2007; Akibode \& Maredia, 2011).

Table 2. Cowpea, Bambara groundnut, and pulses, nes production in Nigeria and other key regions/countries (2016-2018 averages)

\begin{tabular}{|c|c|c|c|c|c|c|}
\hline Legumes & $\begin{array}{l}\text { Major } \\
\text { regions/countries }\end{array}$ & $\begin{array}{l}\text { Area harvested } \\
\text { ('000 ha) }\end{array}$ & $\begin{array}{l}\text { Area } \\
(\%)\end{array}$ & $\begin{array}{l}\text { Production } \\
\left({ }^{\circ} 000 \text { t) }\right.\end{array}$ & $\begin{array}{l}\text { *Production } \\
(\%)\end{array}$ & $\begin{array}{l}\text { Yield } \\
\text { (kg/ha) }\end{array}$ \\
\hline \multirow[t]{24}{*}{ Cowpea } & World & 12391 & $13.42 * *$ & 7016 & $7.81 * *$ & 566 \\
\hline & Africa & 12158 & 98.12 & 6745 & 96.14 & 555 \\
\hline & Northern Africa & 270 & 2.18 & 131 & 1.87 & 480 \\
\hline & Western Africa & 10595 & 85.51 & 5847 & 83.34 & 552 \\
\hline & Eastern Africa & 903 & 7.29 & 503 & 7.17 & 557 \\
\hline & Middle Africa & 376 & 3.03 & 259 & 3.69 & 687 \\
\hline & SEA & 131 & 1.06 & 143 & 2.04 & 1091 \\
\hline & Nigeria & 3081 & 24.86 & 2707 & 38.58 & 883 \\
\hline & Niger & 5648 & 45.58 & 2107 & 30.03 & 373 \\
\hline & Burkina Faso & 1239 & 10.00 & 597 & 8.51 & 482 \\
\hline & Tanzania & 207 & 1.67 & 197 & 2.81 & 955 \\
\hline & Cameroon & 210 & 1.69 & 187 & 2.67 & 890 \\
\hline & Mali & 285 & 2.30 & 155 & 2.21 & 544 \\
\hline & Kenya & 244 & 1.97 & 156 & 2.22 & 641 \\
\hline & Myanmar & 131 & 1.06 & 143 & 2.04 & 1089 \\
\hline & Mozambique & 315 & 2.54 & 83 & 1.18 & 264 \\
\hline & Sudan & 268 & 2.16 & 124 & 1.77 & 456 \\
\hline & DRC & 167 & 1.35 & 72 & 1.03 & 432 \\
\hline & Senegal & 163 & 1.32 & 57 & 0.81 & 373 \\
\hline & Malawi & 94 & 0.76 & 40 & 0.57 & 421 \\
\hline & Haiti & 43 & 0.35 & 31 & 0.44 & 725 \\
\hline & USA & 13 & 0.10 & 23 & 0.33 & 1834 \\
\hline & Peru & 16 & 0.13 & 20 & 0.29 & 1252 \\
\hline & Serbia & 4.8 & 0.04 & 16 & 0.23 & 3368 \\
\hline \multirow[t]{7}{*}{ Bambara nut } & World & 258 & $0.28 * *$ & 187 & $0.21 * *$ & 726 \\
\hline & Burkina Faso & 48 & 18.60 & 55 & 29.41 & 1099 \\
\hline & Cameroon & 49 & 18.99 & 38.88 & 20.79 & 796 \\
\hline & Niger & 71 & 27.52 & 38.53 & 20.60 & 543 \\
\hline & Mali & 39 & 15.12 & 26.3 & 14.06 & 675 \\
\hline & DRC & 26 & 10.08 & 10.87 & 5.81 & 423 \\
\hline & Nigeria & NA & - & $>10 * * *$ & $>5.35$ & NA \\
\hline \multirow{8}{*}{ Pulses, nes } & World & 5487 & $5.94 * *$ & 4135 & $4.60 * *$ & 753 \\
\hline & Southern Asia & 2422 & 44.14 & 1221 & 29.53 & 504 \\
\hline & SEA & 281 & 5.12 & 276 & 6.67 & 981 \\
\hline & Eastern Africa & 950 & 17.31 & 664 & 16.06 & 700 \\
\hline & Western Africa & 811 & 14.78 & 364 & 8.80 & 449 \\
\hline & Nigeria & 147 & 2.68 & 67 & 1.62 & 457 \\
\hline & Eastern Europe & 162 & 2.95 & 373 & 9.02 & 2268 \\
\hline & Northern Europe & 122 & 2.22 & 355 & 8.59 & 2914 \\
\hline
\end{tabular}

Source: http://faostat.fao.org/ *Percent share of each region/country in global area and production of cowpea, Bambara groundnut (BG), or pulses, nes. **Percent share of cowpea, BG, or pulses, nes in global area and production of all pulses. ***Hillocks et al. (2012). NA= not available. Regional grouping of countries (UNSD, 2006)

Nigeria's performance in cowpea production is poor. The area cultivated experienced insignificant growth between 1996-98 and 2006-08 (only 1.1\%) and fell by 30\% at 3.5\% yearly during past decade (2006-08 to 2016-18) (Table 3). Generally, since the 90's, Nigeria's cowpea area has fluctuated, remained stagnant/declined: 
3.3, 3.8, 3.4 and 3.1 million ha in 1990-99, 2000-2009, 2010-2015 and 2016-18, respectively (http://faostat.fao.org). This situation is probably due to the poor productivity gains causing increasing replacement by more profitable grains like soybeans (Kormawa, Chianu, \& Manyong, 2000; Tijjani, Nabinta, \& Muntaka, 2015). Cowpea yield and production may appear to have increased viewed from 1996-98 (97\% at 3.4\% and $40 \%$ at $1.7 \%$ annually, respectively) (Table 3) but are similar in trend to area; the yield 734, 481, 647, 1102, 606 and $883 \mathrm{~kg} / \mathrm{ha}$ in 1990-91, 1992-98, 1999-2008, 2009-13, 2014-15 and 2016-18, respectively (FAOSTAT), the variations attributable to erratic weather patterns and insect attack (Kormawa et al., 2000; Asiwe, 2009; Muchero, Ehlers, \& Roberts, 2010). The production was 1.80, 2.55, 1.64, 5.15, 2.22 and 2.71 million $\mathrm{t}$ in 1995-96, 2003-04, 2011, 2012, 2014-15 and 2016-18, respectively-the fluctuations/stagnation attributable to the lack of area expansion and relatively low/varying yields (compared to over $0.3 \mathrm{t} / \mathrm{ha}$ in developed nations). Nigeria does not produce enough cowpea to meet domestic demand. While the production was projected at 3.4 million $\mathrm{t}$ in 2015, demand was 5.6 million $\mathrm{t}$ - the deficit resulting in importation to make up (Kormawa et al., 2000; Langyintuo et al., 2003; Abate et al., 2012).

Table 3. Growth and growth rates in area, production and yield of cowpea in Nigeria and other major regions (1996-98 to 2016-2018)

\begin{tabular}{lllllllll}
\hline Region & $\mathbf{2 0 0 6 - 0 8}$ & $\mathbf{2 0 1 6 - 1 8}$ & $\begin{array}{l}\text { Growth } \\
(\boldsymbol{\%})\end{array}$ & $\begin{array}{l}\text { Growth } \\
\text { rate (\%) }\end{array}$ & $\mathbf{1 9 9 6 - 9 8}$ & $\mathbf{2 0 1 6 - 1 8}$ & $\begin{array}{l}\text { Growth } \\
(\boldsymbol{\%})\end{array}$ & $\begin{array}{l}\text { Growth } \\
\text { rate (\%) }\end{array}$ \\
\hline AREA (Million ha) & & & & & & & & \\
WORLD & 11.88 & 12.39 & 4.29 & 0.42 & 9.31 & 12.39 & 33.08 & 1.44 \\
Western Africa & 10.46 & 10.59 & 1.24 & 0.12 & 8.61 & 10.59 & 23.00 & 1.04 \\
Nigeria & 4.40 & 3.08 & -30.00 & -3.50 & 4.35 & 3.08 & -29.20 & -1.71 \\
Niger & 4.71 & 5.65 & 19.96 & 1.84 & 3.27 & 5.65 & 72.78 & 2.77 \\
Burkina Faso & 0.87 & 1.24 & 42.53 & 3.61 & 0.56 & 1.24 & 121.43 & 4.05 \\
Eastern Africa & 0.78 & 0.90 & 15.38 & 1.44 & 0.38 & 0.90 & 136.84 & 4.41 \\
Middle Africa & 0.24 & 0.38 & 58.33 & 4.70 & 0.12 & 0.38 & 216.67 & 5.93 \\
SEA & 0.18 & 0.13 & -27.78 & -3.20 & 0.07 & 0.13 & 85.71 & 3.14 \\
Northern Africa & 0.112 & 0.27 & 141.07 & 9.20 & 0.003 & 0.27 & 8900 & 25.23 \\
PRODUCTION & $($ Million t) & & & & & & & \\
WORLD & 5.56 & 7.02 & 26.26 & 2.36 & 3.25 & 7.02 & 116.00 & 3.93 \\
Western Africa & 4.64 & 5.85 & 26.08 & 2.34 & 2.73 & 5.85 & 114.29 & 3.88 \\
Nigeria & 2.99 & 2.71 & -9.36 & -0.98 & 1.94 & 2.71 & 39.69 & 1.69 \\
Niger & 1.09 & 2.11 & 93.58 & 6.83 & 0.40 & 2.11 & 427.50 & 8.67 \\
Burkina Faso & 0.41 & 0.60 & 46.34 & 3.88 & 0.26 & 0.60 & 130.77 & 4.27 \\
Eastern Africa & 0.39 & 0.50 & 28.21 & 2.52 & 0.24 & 0.50 & 108.33 & 3.74 \\
Middle Africa & 0.18 & 0.26 & 44.44 & 3.75 & 0.08 & 0.26 & 225.00 & 6.07 \\
SEA & 0.19 & 0.14 & -26.32 & -3.01 & 0.06 & 0.14 & 133.33 & 4.33 \\
Northern Africa & 0.041 & 0.13 & 217.07 & 12.23 & 0.006 & 0.13 & 2067.00 & 16.62 \\
YIELD (kg/ ha) & & & & & & & & \\
WORLD & 468 & 566 & 20.94 & 1.92 & 348 & 566 & 62.64 & 2.46 \\
Western Africa & 443 & 552 & 24.60 & 2.22 & 316 & 552 & 74.68 & 2.83 \\
Nigeria & 679 & 883 & 30.04 & 2.66 & 449 & 883 & 96.66 & 3.44 \\
Niger & 226 & 373 & 65.04 & 5.14 & 119 & 373 & 213.45 & 5.88 \\
Burkina Faso & 470 & 482 & 2.55 & 0.25 & 459 & 482 & 5.01 & 0.24 \\
Eastern Africa & 498 & 557 & 11.85 & 1.13 & 635 & 557 & -12.28 & -0.65 \\
Middle Africa & 750 & 687 & -8.40 & -0.87 & 670 & 687 & 2.54 & 0.13 \\
SEA & 1094 & 1091 & -0.27 & -0.03 & 807 & 1091 & 35.19 & 1.52 \\
Northern Africa & 328 & 480 & 46.34 & 3.88 & 2331 & 480 & -79.41 & -7.60 \\
\hline
\end{tabular}

Source: Calculated from FAOSTAT. GR, Growth Rate

Except in Southeastern Asia (SEA) where area under cowpea also fluctuated, area for cowpea received steady and positive growth in other major countries/regions (Figure 1a) rising by $73 \%$ at $2.8 \%$ annually (Niger), $121 \%$ at $4.1 \%$ (Burkina Faso), $137 \%$ at $4.4 \%$ (Eastern Africa), $217 \%$ at $5.9 \%$ (Middle Africa) and 90 fold in Northern Africa where cowpea area was insignificant in 1996-98 (3000 ha) but rose to 0.27 million ha in 2016-18 (Table 3 ). The deficit in Nigeria had a major impact globally and in Western African, cowpea area rising by only $4.3 \%$ at $0.42 \%$ and $1.24 \%$ at $0.12 \%$, respectively between $2006-08$ and $2016-18$ (Table 3 ). 
Niger recorded steady and the highest growth in yield during the 20-year period (213\% at $5.9 \%)$ and with Nigeria largely accounted for the increase in mean cowpea yield in Western Africa (75\% at 2.8\%) and globally (63\% at 2.5\%) (Table 3). Yield is stagnant or declined in other regions (Figure 1a). Also, Niger and Northern Africa had steady and the most significant increase in production ( $428 \%$ at $8.7 \%$ annually, and 22 fold increase, respectively), Niger due to area expansion and yield increase, and Northern Africa, area expansion as yield declined (Table 3). Production also rose steadily and substantially in other cowpea regions due to area and/or yield increase, except in SEA, where like Nigeria, it fluctuated also due to loss in area (Figure 1a).

\subsection{Production of Minor Pulses in Nigeria Compared to Global and Regional Production}

Other pulses grown in Nigeria include Bambara bean (Vigna subterranean), pigeon pea (Cajanus cajan), African yam bean (Sphenostylis stenocarpa), local cowpea varieties (Vigna sinensis), ground (Kerstingeilla geocarpa), jack (Canavalis ensiformis), velvet beans (Mucuna pruriens), Lima and kidney beans (Phaseolus spp) (Fasoyiro, Ajibade, Omole, Adeniyan, \& Farinde, 2006; Apata, 2008; Okeke et al., 2008; Ene-Obong et al., 2013; Obiakor-Okeke, 2014). Up to 10 pulse species were documented for the Igbo area alone (Okeke et al., 2008). These minor pulses are also valuable food security and economic crop in many localities in Nigeria (Aviara, Lawal, Atiku, \& Haque, 2013; Okeke et al., 2008; Ene-Obong et al., 2013; Nnamani et al., 2017). However, their production is low and the statistics not usually available. Just over $10000 \mathrm{t}$ yearly is reported for Bambara nut (Hillocks, Bennett, \& Mponda, 2012; Aviara et al., 2013) but there is no record of the production against Nigeria in FAOSTAT although the value is close to $10870 \mathrm{t}$ for Democratic Republic of Congo (DRC) (Table 2). Only five countries in Africa are reflected in FAO data for Bambara beans but more countries including Nigeria like Chad, Ghana and Zambia with significant productions are reported (Barimalaa, Agoha, Oboh, \& Kiin-Kabari, 2005; Hillocks et al., 2012; Aviara et al., 2013). FAOSTAT also reports about 200000 t Bambara bean annually globally but over $330000 \mathrm{t}$ is produced in Africa yearly (Hillocks et al., 2012). Thus, it appears that production data in FAOSTAT for some/minor pulses is not captured/are hidden under pulses, nes for countries where their data is not supplied (Akibode \& Maredia, 2011).
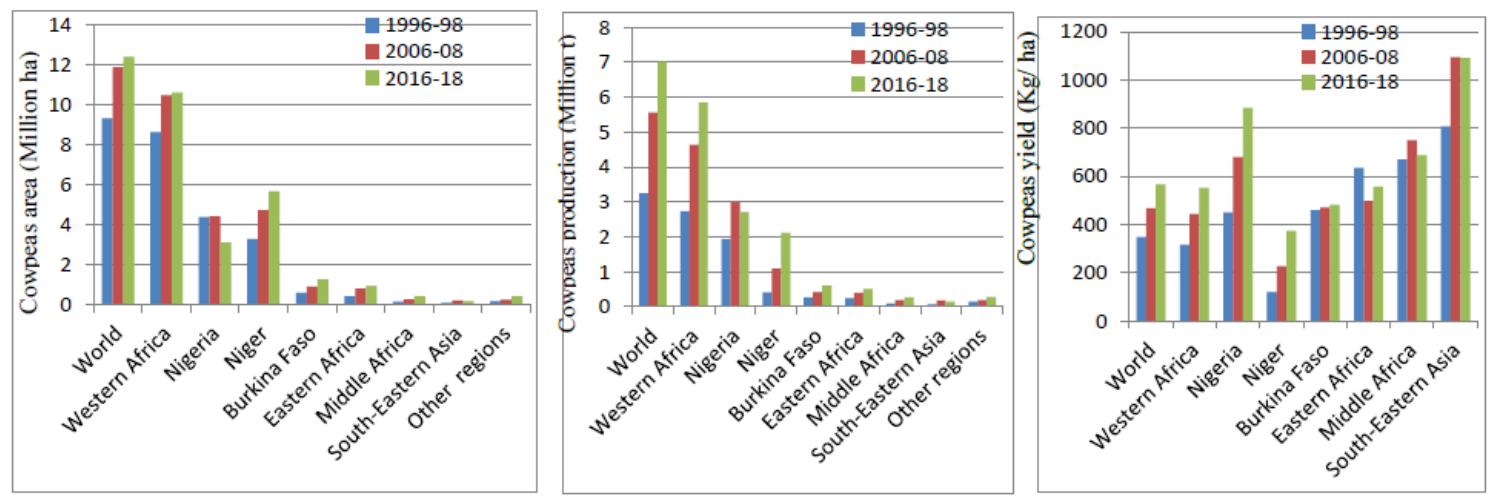

Figure 1a. Trend in area, production and yield of cowpeas in Nigeria and major regions/countries
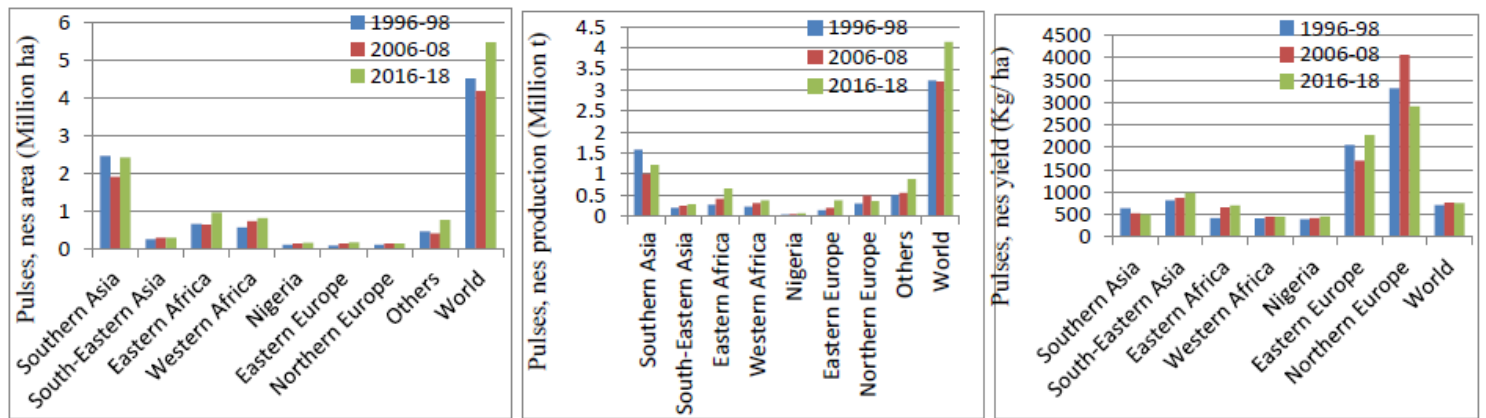

Figure 1b. Trend in area, production and yield of pulses, nes in Nigeria and major regions/countries

Total pulse area in Nigeria in 2016-18 is 3.2 million ha and production 2.8 million $\mathrm{t}$ (Table 1). Cowpea represented $95.45 \%$ area and $97.55 \%$ production and pulses, nes with 147000 ha and $67000 \mathrm{t}, 4.55 \%$ and $2.41 \%$, respectively; thus, other pulses were accounted for under pulses, nes in FAOSTAT. Nigeria accounted for $2.7 \%$ 
global pulses, nes area and 1.6\% production in 2016-18 but made significant contributions $(18.13 \%$ area and $18.41 \%$ production) in Western Africa. Southern Asia followed by Eastern Africa tops in the production (Table 2).

Area for pulses, nes in Nigeria rose by 67\%, yield (14\%) and production (75\%), Western Africa similarly (45, 7 and $61 \%$, respectively) (Figure 1b). The area stagnated/declined in Southern Asia while the production and yield fell (23 and 21\%, respectively). SEA and Northern Europe experienced no growth in the area between 2006-08 and 2016-18 but yield and production increased in SEA (17 and 13\%, respectively), while they fell in Northern Europe (28 and 27\%, respectively) (Figure 1b). The area rose in Eastern Africa from 0.65 million ha (1996-98) to 0.95 million ha (2016-18), yield by 65\% and production 2.44 fold (Figure 1b); however, the area is stagnant/fell viewed from early 90's (1.19 million ha, 1990-95) (http://faostat.fao.org). The area rose in Eastern Europe by $50 \%$, production 2.64 fold, while the yield fluctuated (Figure 1b). The global area experienced overall stagnation similar to Eastern Africa (5.61, 4.53, 4.19, 5.49 million ha: 1990-93, 1996-98, 2006-08, 2016-18, respectively) (http://faostat.fao.org); the production was steady/stagnant but increased (29\%) between 2006-08 and 2016-18 (Figure 1b). Production of diverse minor pulses seems to have received increasing interest especially in Nigeria probably due to increasing awareness of benefits of diversification (Ene-Obong et al., 2013). However, their mean yield in Nigeria is quite poorer than cowpeas' (Table 2) showing exceptionally marginal inputs.

\subsection{Constraints to Cowpea Production in Nigeria and Way Forward}

Cowpea production is constrained by poor yield, the poorest among legumes with an average of $450 \mathrm{~kg} / \mathrm{ha}$ in Sub-Saharan Africa (SSA) (Asiwe, 2009; Akibode \& Maredia, 2011; Abate et al., 2012; Ahmad \& Kiresur, 2016) although yields above $4000 \mathrm{~kg} / \mathrm{ha}$ is common in developed regions (Timko et al., 2007). A major cause is pest attack with losses of 20-over $90 \%$ by field pests like Aphis craccivora, Megalurothrips sjostedti, and Maruca vitrata in Nigeria, Cameroun and some other producing countries, and up to $100 \%$ by the storage pest, Callosobruchus maculatus reported (Asiwe, 2009; Muchero et al., 2010; Sanon, Ba, Binso-Dabire, \& Pittendrigh, 2010; Akah \& Onyeka, 2017). Diseases, drought, low soil fertility and parasitic weeds are also major constrains to cowpea and other legumes' production in SSA (Kormawa et al., 2000; Asiwe, 2009; Abate et al., 2012; Aviara et al., 2013; Fischer, Byerlee \& Edmeades, 2014).

Adoption of improved inputs and agronomic/cultural practices can boost cowpea production, reduce importation and improve nutritional security in Nigeria and other places (Agwu, 2004; Ogban et al., 2008; Asiwe, 2009; Tijjani et al., 2015; Ahmad \& Kiresur, 2016; Kamara et al., 2016). The recent positive agricultural growth in Nigeria that raised food production and substantially reduced importation (FAO, 2017) shows that cowpea production can be greatly improved if accorded favorable policies mainly directed at cereals and roots/tubers regarded as chief to food security (Kormawa et al., 2000; Abate et al., 2012; Ene-Obong et al., 2013). However, improved production of other pulses is also important (Ahmad \& Kiresur, 2016) as minor pulses like Bambara and African yam beans are hardier (Hillocks et al., 2012; Adewale \& Odoh, 2013). Pulses also differed in nutritional composition reflecting the benefits of consuming diverse legumes (Ene-Obong et al., 2013). In addition, Nigeria's diversification in pulse production is important to meet individual/cultural preferences (Nnamani et al., 2017).

\subsection{Pulse Consumption in Nigeria Relative to Global and Regional Consumption}

Global pulse per capita availability/consumption is low and generally remain stagnant/declined varying from about $9.4 \mathrm{~kg} / \mathrm{capita} / \mathrm{year}$ (70's) to $6.5 \mathrm{~kg}$ (90's to 2000's) (Akibode \& Maredia, 2011; OECD/FAO, 2016) to 6.92 $\mathrm{kg}$ (2010-13) (0.78-16.4 kg, Central Asia-Eastern Africa), and far below cereals' $147 \mathrm{~kg}(90-216 \mathrm{~kg}$, Oceania-Northern Africa) and roots/tubers' $63 \mathrm{~kg}$ (17-205 kg, Central America-Western Africa) (Table 4). The daily protein supply is $7.7 \%$ (1-18.8\%, Central Asia-Eastern Africa) while cereals supply $60 \%$; the calorie supply is $2.6 \%(<1-6 \%$, Central Asia-Eastern Africa), cereals' is $>50 \%$ (Table 4). The availability in Nigeria is $10.57 \mathrm{~kg}$ increasing since $1995-97$ by $15 \%$ and $1985-87$ by 2.42 fold, yet incomparable to cereals' $(138.7 \mathrm{~kg})$ and roots/tubers' (244.57 kg) (13 and 23 times lower availability, respectively), and quite less than Rwanda's $35.5 \mathrm{~kg}$ (http://faostat.fao.org/) and Burundi's $40.7 \mathrm{~kg}$ (Schneider, 2002). Cereals also supply over 50\% of Nigeria's daily protein intake, roots/tuber $12.5 \%$, pulses $12 \%$; cereals supply about half the calories, roots/tubers $24 \%$, pulses only $4 \%$ (Table 4) while pulses supply up to $38 \%$ protein in Rwanda and 55\% (Burundi) (Akibode \& Maredia, 2011). Pulse consumption since 1995-97 also increased in Central Asia (3 fold), Eastern, Middle, Western Africa, Caribbean, SEA (22-57\%), Northern Africa, Northern America, Southern and Western Asia (6-10\%), steady in South America (0.67\%), and declined in Southern Africa, Central America, Europe, Oceania, and Eastern Asia (9-21\%) (http://faostat.fao.org/). Nevertheless, the consumption remains quite poor compared to other staples' 
(Table 4). Also, regional trend masks trends by countries like Rwanda (Eastern Africa) where the consumption, overall, declined/is steady (38.7 kg [1985-87], $25 \mathrm{~kg}$ [1995-97]) (http://faostat.fao.org/).

Table 4. Pulses: per capita availability (kg/cap/yr) and average daily contribution to calorie and protein intake (\%) relative to cereals and roots/tubers (2010-13 averages)

\begin{tabular}{llllllllll}
\hline Region & Pulses & \multicolumn{3}{c}{ Cereals } & \multicolumn{3}{c}{ Roots/tuber } \\
\cline { 2 - 10 } & $\begin{array}{l}\text { Per capita } \\
(\mathrm{kg})\end{array}$ & $\begin{array}{l}\text { Calorie } \\
(\%)\end{array}$ & $\begin{array}{l}\text { Protein } \\
(\%)\end{array}$ & $\begin{array}{l}\text { Per capita } \\
(\mathrm{kg})\end{array}$ & $\begin{array}{l}\text { Calori } \\
\mathrm{e}(\%)\end{array}$ & $\begin{array}{l}\text { Protein } \\
(\%)\end{array}$ & $\begin{array}{l}\text { Per capita } \\
(\mathrm{kg})\end{array}$ & $\begin{array}{l}\text { Calorie } \\
(\%)\end{array}$ & $\begin{array}{l}\text { Protein } \\
(\%)\end{array}$ \\
\hline World & 6.92 & 2.6 & 7.74 & 147 & 52 & 60 & 63 & 5.6 & 4.25 \\
Developed regions & 2.92 & 1.08 & 3.4 & 110 & 34 & 48 & 66.4 & 4.5 & 5.23 \\
Developing regions & 8.26 & 3.08 & 9.33 & 146 & 50 & 60.4 & 75 & 7.1 & 4.72 \\
Northern Africa & 7.26 & 2.74 & 8.98 & 216 & 71.44 & 94.34 & 41 & 3.33 & 2.81 \\
Sub-Saharan Africa & 10.73 & 4.0 & 12.2 & 137 & 47 & 57.4 & 138 & 14.4 & 6.26 \\
Eastern Africa & 16.4 & 6.1 & 18.75 & 121.5 & 42.43 & 51.89 & 124 & 13.2 & 7.2 \\
Middle Africa & 12.1 & 4.42 & 13.57 & 108 & 35 & 44.2 & 184 & 20 & 9.7 \\
Southern Africa & 3.27 & 1.2 & 3.7 & 175.2 & 60 & 75.4 & 39.2 & 3.2 & 3.1 \\
Western Africa & 11.15 & 4.13 & 12.75 & 145 & 49 & 58 & 205 & 21.2 & 11.4 \\
Nigeria & 10.57 & 3.9 & 12.3 & 139 & 47.3 & 58 & 245 & 24 & 12.51 \\
Central Asia & 0.78 & 0.29 & 0.90 & 163 & 51 & 69 & 68 & 5.0 & 5.6 \\
Eastern Asia & 1.49 & 0.54 & 1.68 & 147 & 56 & 62 & 63.25 & 5.65 & 4.6 \\
Southern .Asia & 11.86 & 4.51 & 12.7 & 155.49 & 56.53 & 63 & 32 & 2.51 & 2.3 \\
South-eastern Asia & 3.18 & 1.18 & 3.51 & 170 & 62 & 59.4 & 39 & 4.2 & 1.53 \\
Western Asia & 8.54 & 3.24 & 9.28 & 182 & 59.4 & 80.26 & 33 & 2.5 & 2.64 \\
Northern America & 4.56 & 1.71 & 5.45 & 107 & 32.3 & 45.28 & 59.22 & 3.8 & 4.77 \\
Caribbean & 14.91 & 5.52 & 16.43 & 106 & 38 & 42.1 & 75.1 & 7.51 & 4.23 \\
Central America & 12.05 & 4.55 & 13.02 & 151 & 50.66 & 61.6 & 16.65 & 1.26 & 1.02 \\
South America & 10.57 & 3.91 & 12.1 & 115.46 & 38.6 & 44 & 64 & 5.83 & 4.4 \\
Oceania & 2.06 & 0.74 & 3.28 & 91.63 & 30.27 & 41 & 66 & 3.6 & 5.51 \\
Australia \& New Zealand & 1.66 & 0.6 & 1.85 & 90.49 & 29.69 & 41.21 & 56.87 & 3.65 & 4.3 \\
Europe & 2.54 & 0.94 & 2.89 & 132 & 40.4 & 57 & 83 & 6 & 6.62 \\
\hline
\end{tabular}

Source: Calculated from FAOSTAT Food Balance Sheet. Energy calculated based on mean supply of $2500 \mathrm{Kcal} / \mathrm{cap} /$ day for normal healthy adult male and female 55-70 kg (FAO, 2001). Percent daily protein supply calculated based on WHO/FAO/UNU 1985 mean requirement (53 g) for $70 \mathrm{~kg}$ adult male (Azeke et al., 2005). Cereals, pulses and roots include all categories in FAOSTAT. Cereals: wheat and products; rice (milled equivalent); barley and products; maize and products; rye and products; oats; millet and products; sorghum and products; and cereals, other. Pulses: beans; peas; and pulses, other and products. Roots: cassava and products; potatoes and products; sweet potatoes; yams; and roots, other. Regional grouping of countries (UNSD, 2006).

Roots/tubers per capita availability in Nigeria is higher than in any other country/region and they are eaten more than any other staple. Cassava and yam and products are eaten almost daily once-more by over $70 \%$ in Southern Nigeria, cereals similarly in Northern region (Ene-Obong et al., 2013). Cereals and especially roots/tubers contain quite less amounts of protein than pulses. Low pulse consumption is, therefore, a major contributing factor to the prevalent malnutrition. This is similar across Sub-Saharan Africa where animal protein is scarce and poorly eaten due to poverty. In contrast, protein supply in developed countries is excess much from animal sources. However, over-consumption is also associated with high risk of non-communicable diseases and increased pulse intake is advocated (Okeke et al., 2008; Schonfeldt \& Hall, 2012; FAO, 2016; IFPRI, 2017; Palmer, Winham, Oberhauser, \& Litchfield, 2018; Frankenfeld \& Wallace, 2020; Szczebyło, Rejman, Halicka, \& Laskowski, 2020).

The data presented represent net availability and not actual consumption which is often lower. Pulse consumption in India in 2004-05 from a household survey was about $8.7 \mathrm{~kg} / \mathrm{capita} /$ year but FAO estimate 11.7 $\mathrm{kg}$ (Akibode \& Maredia, 2011). Per capita protein consumption in USA in 1990-92 was overestimated by FAO by over 20\% based on the 1988-1991 Health and Nutrition Examination Survey (Schonfeldt \& Hall, 2012). Polish pulse consumption in the last two decades from the Household Budget Surveys' data is 0.6-0.9 $\mathrm{kg} / \mathrm{capita} / \mathrm{year}$ (20-30 times less than $18.25 \mathrm{~kg}$ recommended) but FAO's 1.86-2.01 kg (2014-17) (Szczebyło et al., 2020). However, household consumption data from three major cities in Northern Nigeria indicated 8 $\mathrm{kg} /$ week (> $50 \mathrm{~kg} /$ person/year) for cowpea and Bambara nut (Kormawa et al., 2000) but this is inconsistent with other data sources and not nationally representative (Langyintuo et al., 2003). Actual consumption is limited by factors like availability, income/cost, access, preferences and culture. Others peculiar to pulses include hard-to-cook defect, flatulence, urbanization (leads to dietary shifts and demand for convenience foods), and off-flavor/taste. Boosting production/availability; improving the traditional products/creating diverse, innovative, cheap, balanced/healthy and tasteful products; increased awareness of better culinary methods and health 
benefits; and favorable policies are some key ways to tremendously improve pulse demand/consumption in Nigeria and other places (Rackis, Sessa, \& Honig, 1979; Uebersax, Ruengsakulrach, \& Occena, 1991; Schneider, 2002; Akibode \& Maredia, 2011; Hillocks et al., 2012; Ene-Obong et al., 2013; FAO, 2016; OECD/FAO, 2016; FAO, 2017; IFPRI, 2017; Nnamani et al., 2017; Aseete, Katungi, Bonabana-Wabbi, Birachi, \& Ugen, 2018; Palmer et al., 2018; Frankenfeld \& Wallace, 2020; Szczebyło et al., 2020).

\subsection{Utilization of Pulses in Nigeria and Other Regions}

Nigeria's legume consumption also revolves around cowpea but the minor pulses also have their place, a situation similar in other parts of Western Africa (Kormawa et al., 2000; Okeke et al., 2008; Ene-Obong et al., 2013; Yellavila, Agbenorhevi, Asibuo, \& Sampson, 2015). The pulses are primarily produced for direct human consumption (Kormawa et al., 2000; Langyintuo et al., 2003); the products include pottage, beans and rice, 'ayaraya', steamed/fried pastes, snacks, and fermented condiments.

The pottage is prepared by cooking beans with ingredients like palm oil, pepper, salt, onion, crayfish/fish and/or vegetables. It is eaten alone or with 'ogi', bread or soaked-'garri'; or cooked together with cereals, yam, ripe/unripe plantain, or potatoes. Bean sauces/soups are popular in some parts like 'gbegiri' a Yoruba bean sauce - cowpea is soaked, dehulled, cooked, mashed, ingredients, more water added and mixture cooked to taste. The Northern part commonly eats cowpea grains in soup. Rice and bean grains are cooked separately or together and served with stew prepared with ingredients like tomatoes, onion, pepper, fish and seasonings; or cooked together with ingredients 'jollof' (Kormawa et al., 2000; Madukwe \& Ene-Obong, 2002; Okeke et al., 2009; Akinlua, Sedodo, \& Victoria, 2013; Aviara et al., 2013; Ene-Obong et al., 2013; Nnamani et al., 2017). Pulses are also commonly eaten with other foods especially cereals in other parts of Africa like Congolese rice and bean dish 'loso na madesu', Ghanaian rice and cowpea grains served with stew 'waakye', Kenyan puree of pulses and cereals 'irio' and bean-maize grains dish 'githeri'. Pulse and cereal dishes are also popular in other places across the world like USA, Mexico and Asia (APO Report, 2003; Wilhelmina et al., 2010; FAO, 2016).

'Ayaraya' is a mixture of bean/fresh pods and maize 'oka', yam 'ji', or dried cocoyam 'achicha'. 'Ayaraya' is popular as home/vended food in Nsukka, Southeastern Nigeria where it is often prepared with pigeon pea. It is also eaten in North-central Nigeria. After cooking and draining, yam is cut to small pieces/crumbled and mixed with pigeon pea, vegetables (optional), and palm-oil heated with ingredients like onion, pepper, salt, and/or fermented Pentaclethra macrophylla 'ukpaka': 'ayaraya-ji'. Maize is soaked in water for $6 \mathrm{~h}$ or more, drained, ground, mixed with water, salt and palm oil (optional) (fresh corn may be used but is not soaked), steamed over boiling water in local steamer (often in same pot as pigeon pea), gelatinized paste crumbled and mixed with pigeon pea and palm oil-sauce: 'ayarara-oka'. Fresh cocoyam is boiled in its skin till reddish-brown, peeled, cut to pieces, and dried (sun and/or above fireplace). The chips is broken to smaller pieces, soaked in water for about $2 \mathrm{~h}$, washed, squeezed between palms to drain, steamed in steamer/cellophane, and mixed with pigeon pea and palm oil-sauce: 'ayarara-achicha' (Ene-Obong \& Obizoba, 1995; Madukwe \& Ene-Obong, 2002; Okeke et al., 2009; Ene-Obong et al., 2013; Ifeanyieze \& Okeme, 2014; Nnamani et al., 2017). African yam bean (AYB) 'ijiriji' and fresh pods/dry seeds of local cowpea varieties 'akidi' among others are also mixed with fermented-washed cassava strips 'abacha' and palm oil-sauce- 'ijiriji-na-abacha' and 'akidi-na-abacha', respectively (Okeke et al., 2009).

The puddings are made from dehulled/undehulled, wet/dry-milled cowpea, Bambara nut, or AYB. The paste is mixed with ingredients like oil, onion, pepper, salt, crayfish and/or bouillon cubes and steamed (in leaves/recycled containers/cellophane/aluminum foil)/deep-fried. They are 'moimoi', 'okpa', 'ugbagidi' (steamed cowpea, Bambara nut, AYB pastes, respectively) and 'akara' (fried pastes, respectively). They are eaten alone or with foods like 'ogi' as breakfast, or rice and bread as lunch/dinner. Their acceptability depends on taste, gel firmness and appearance/color. Stiff pudding/porridge/'fufu' of Bambara beans and AYB among others, alone or combined with cereals/roots/tubers eaten with soups/sauces is popular in some parts (Uvere, Uwaegbute \& Adedeji, 1999; Madukwe \& Ene-Obong, 2002; Barimalaa et al, 2005; Okeke et al., 2009; Aviara et al., 2013; Ene-Obong et al., 2013; Ifeanyieze \& Okeme, 2014; Nnamani et al., 2017). Steamed/fried cowpea pastes like 'toubani/tubani' (served with sauce/stew) and 'koose' are popular in Benin and Ghana (Wilhelmina et al., 2010; Abizari et al., 2012; Hongbété et al., 2017). AYB pudding is eaten in Ghana (Klu et al., 2001). Deep-fried bean pastes are also popular in Mediterranean and Middle Eastern cultures, and Southern Asia (FAO, 2016).

The puddings are cheap, readily available as street food, and indispensable in Nigeria- 'okpa' is a breakfast food for at least 5 million people including children in North-central Nigeria (Igbabul, Adole, \& Sule, 2013), and also a major breakfast food in Enugu, Southeastern Nigeria (Wikipedia). Similarly, 'toubani' is a staple in Benin eaten once-several times/week as breakfast/lunch/dinner (Hongbété et al., 2017). They, due to low glycemic index, 
also offer better alternative as convenience healthy foods compared to excessive-caloric items like bread, biscuit, and pasta (Onimawo, Ijeh, Ukoha, \& Nwachukwu, 2007; Akinlua et al., 2013; Ene-Obong et al., 2013; IFPRI, 2017). Pulses' utilization in Nigeria and regionally/globally is summarized in Table 5.

Table 5. Traditional and non-traditional utilization of legumes in Nigeria and regionally/globally

\begin{tabular}{|c|c|c|c|}
\hline Legumes & Preparation methods/recipes/products/uses & Consumption areas & References \\
\hline $\begin{array}{l}\text { Most pulses: whole } \\
\text { seeds/dhal }\end{array}$ & $\begin{array}{l}\text { Boiling/cooking, frying, sautéing, and/or mashing (with } \\
\text { ingredients and/or other foods): } \\
\text { Bean sauces/stews/soups, porridge, broth, gruel, } \\
\text { gravies, curries, pottage, purees/pastes, beans and } \\
\text { rice/yam/potatoes }\end{array}$ & Global & $\begin{array}{l}\text { Uebersax et al., 1991; APO } \\
\text { Report, 2003; FAO, 2016; } \\
\text { Frankenfeld \& Wallace, } \\
2020\end{array}$ \\
\hline $\begin{array}{l}\text { Peas, Phaseolus spp, } \\
\text { mung beans, Bambara } \\
\text { groundnut } \quad(\mathrm{BG}), \\
\text { lentils, chickpea, etc. }\end{array}$ & $\begin{array}{l}\text { Ingredients (flours, pastes, bean) in desserts, sweets, } \\
\text { fillings, stuffing; condiments, extenders, emulsifiers, } \\
\text { and/or binders/thickeners in bread, pies, tortillas, } \\
\text { sausages, soups, casseroles, sweet/savory dishes and/or } \\
\text { salads }\end{array}$ & $\begin{array}{l}\text { Many places in Asia, } \\
\text { Africa, Americas, } \\
\text { Mediterranean } \\
\text { cultures, Europe }\end{array}$ & $\begin{array}{l}\text { Hillocks et al., 2012; FAO, } \\
2016\end{array}$ \\
\hline Many legumes & $\begin{array}{l}\text { Flours/purees/paste: production/enrichment of } \\
\text { cereal/other flours, porridges, weaning foods, snacks, } \\
\text { bread, cakes, cookies }\end{array}$ & Global & $\begin{array}{l}\text { Uebersax, 2006; Hillocks et } \\
\text { al., 2012; FAO, } 2016\end{array}$ \\
\hline $\begin{array}{l}\begin{array}{l}\text { Mung, } \\
\text { haricot/navy }\end{array} \\
\begin{array}{l}\text { common, } \\
\text { lentils, } \\
\text { chickpeas }\end{array}\end{array}$ & $\begin{array}{l}\text { Protein concentrates/isolates; precooked flours, flakes, } \\
\text { instant powders, canned beans/bean soup, frozen beans }\end{array}$ & $\begin{array}{l}\text { Industrialized regions } \\
\text { mainly }\end{array}$ & $\begin{array}{l}\text { Uebersax, } 2006 ; \\
\text { Langyintuoa et al., 2003; } \\
\text { FAO, 2016; Frankenfeld \& } \\
\text { Wallace, 2020 }\end{array}$ \\
\hline Chickpeas & $\begin{array}{l}\text { Cooking, mashing, blending with ingredients: } \\
\text { 'Hummus' (spread) }\end{array}$ & $\begin{array}{l}\text { Mediterranean, } \\
\text { Middle } \\
\text { cultures, Eastern } \\
\text { Northern Aurope, } \\
\text { India }\end{array}$ & $\begin{array}{l}\text { FAO, 2016; Frankenfeld \& } \\
\text { Wallace, } 2020\end{array}$ \\
\hline Chickpeas/fava beans & $\begin{array}{l}\text { Wet-dehulling, milling, mixing } \quad \text { with } \\
\text { spices/herbs/vegetables, deep-frying: 'Falafel' }\end{array}$ & $\begin{array}{l}\text { Mediterranean, } \\
\text { Middle Eastern } \\
\text { cultures }\end{array}$ & FAO, 2016 \\
\hline 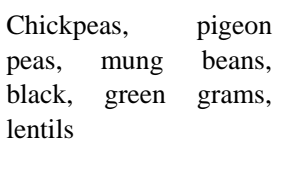 & $\begin{array}{l}\text { Steamed/fried fermented cereal (rice)-bean batter: } \\
\text { 'Idli', 'dosa'/'uttappam', 'dhokla' (breakfast foods); } \\
\text { Fried/dry-heat cooked } \\
\text { 'Fritters'/'falafel', 'papad', 'seviya', 'chakli', } \\
\text { 'roti'/'chapati' (flat bread) }\end{array}$ & Asia & $\begin{array}{l}\text { Uebersax, 1991; APO } \\
\text { Report, 2003; Hemalatha et } \\
\text { al 2007; FAO, } 2016\end{array}$ \\
\hline $\begin{array}{l}\text { Mung bean, black } \\
\text { gram, pigeon pea, } \\
\text { chickpeas }\end{array}$ & Noodles (mung bean tops) & Asia & APO Report, 2003. \\
\hline Cowpea & $\begin{array}{l}\text { Wet-dehulled-milled } \\
\begin{array}{l}\text { batter and } \\
\text { 'Moimoi'/'toubani' }\end{array} \text { (steamed), 'akara'/'koose' } \\
\text { (deep-fried) }\end{array}$ & $\begin{array}{l}\text { Nigeria, } \\
\text { Africa }\end{array}$ & $\begin{array}{l}\text { Madukwe \& Ene-Obong, } \\
\text { 2002; Langyintuoa et al., } \\
\text { 2003; Wilhelmina et al., } \\
\text { 2010; Hongbété et al., } 2017\end{array}$ \\
\hline BG & $\begin{array}{l}\text { Dry/wet-decorticated-milled batter plus ingredients, } \\
\text { steamed: 'Okpa' }\end{array}$ & Nigeria & $\begin{array}{l}\text { Madukwe \& Ene-Obong, } \\
\text { 2002; Barimalaa et al., } 2005 .\end{array}$ \\
\hline $\begin{array}{l}\text { African yam bean } \\
\text { (AYB) }\end{array}$ & $\begin{array}{l}\text { Undecorticated toasted seeds, milled, mixed with } \\
\text { water, ingredients to thick batter, steamed: 'Ugbagidi' }\end{array}$ & Nigeria, Ghana. & $\begin{array}{l}\text { Klu et al., 2001; Ifeanyieze } \\
\text { \& Okeme, } 2014\end{array}$ \\
\hline $\begin{array}{l}\text { Pigeon pea, AYB, local } \\
\text { cowpea varieties, etc. }\end{array}$ & $\begin{array}{l}\text { 'Ayaraya': Bean mixed with crushed maize, yam or } \\
\text { cocoyam chips, and palm oil-sauce }\end{array}$ & $\begin{array}{l}\text { North-central, } \\
\text { Southeastern Nigeria }\end{array}$ & $\begin{array}{l}\text { Madukwe \& Ene-Obong, } \\
\text { 2002; Ene-Obong, et al., } \\
\text { 2013; Ifeanyieze \& Okeme, } \\
\text { 2014; Nnamani et al., } 2017\end{array}$ \\
\hline $\begin{array}{l}\text { Groundnut, soybean, } \\
\text { BG, AYB, dry peas, } \\
\text { chickpeas, lentils }\end{array}$ & $\begin{array}{l}\text { Boiling (immature/mature fresh pods/nuts/seeds), } \\
\text { toasting/roasting/frying (fresh/dry nuts/seeds): Snacks }\end{array}$ & $\begin{array}{l}\text { Global (groundnut), } \\
\text { Asia, Western Africa, } \\
\text { Nigeria }\end{array}$ & $\begin{array}{l}\text { APO Report, 2003; Okeke et } \\
\text { al., 2008; Hillocks et al., } \\
\text { 2012; Aviara et al., 2013; } \\
\text { Ifeanyieze \& Okeme, 2014; } \\
\text { FAO 2016; Nnamani et al., } \\
2017\end{array}$ \\
\hline Lupines, Chickpeas & Brining, pickling: Snack/pickled dish & $\begin{array}{l}\text { South America, } \\
\text { Australia, Europe, } \\
\text { Russia, Turkey }\end{array}$ & FAO, 2016 \\
\hline Soybean, BG, AYB & Wet extraction: Vegetable milk & $\begin{array}{l}\text { Worldwide (soymilk), } \\
\text { Western Africa, } \\
\text { Nigeria }\end{array}$ & $\begin{array}{l}\text { Nnam, 1997; APO Report, } \\
\text { 2003; Hillocks et al., 2012; } \\
\text { FAO, 2016 }\end{array}$ \\
\hline Soybean & $\begin{array}{l}\text { Unfermented: 'tofu', 'yuba', cheese; fermented foods: } \\
\text { soy sauce/paste, 'miso', 'natto', 'tempeh', } \\
\text { 'kap-mu-tiem', fermented 'tofu', fermented whole bean }\end{array}$ & Asia & APO Report, 2003 \\
\hline African locust and oil & Fermentation: & Nigeria & Ogbonna, \\
\hline
\end{tabular}




\begin{tabular}{|c|c|c|c|}
\hline $\begin{array}{l}\text { bean, soybean, BG, } \\
\text { AYB }\end{array}$ & $\begin{array}{l}\text { Condiments- 'Dawadawa'/'iru', 'ogiri', } \\
\text { 'okpei'/'ogiri-okpei', 'ugba'/'ukpaka' }\end{array}$ & 'owoh', & $\begin{array}{l}\text { Achinewhu, 2001; Wokoma } \\
\& \quad \text { Azigba, 2001; Achi, } \\
\text { 2005; Okeke et al., } 2008\end{array}$ \\
\hline $\begin{array}{l}\text { Mung bean, green, } \\
\text { black grams, soybean, } \\
\text { chickpea, broad beans }\end{array}$ & Sprouting: Bean sprouts & Asia, USA & $\begin{array}{l}\text { Uebersax 1991; APO } \\
\text { Report, 2003; Hemalatha et } \\
\text { al., 2007; FAO, } 2016\end{array}$ \\
\hline
\end{tabular}

\subsection{Improving the Quality of Local Bean Dishes in Nigeria}

The dishes described often vary in recipe. Nutritional inadequacy of many Nigerian dishes is blamed on lack of recipe standardization/right food combinations due to factors like preferences, socio-economic status, ignorance and culture. Cereal-legume complementation is especially advocated making beans and rice and 'ayaraya-oka' dishes adequate; however, amounts combined are not considered locally (Ene-Obong \& Obizoba, 1995; Madukwe \& Ene-Obong, 2002). Ene-Obong and Obizoba (1995) showed 70:30 pigeon pea/AYB: corn ideal using experimental rats, performing similarly to casein. This finding can be exploited in improving the puddings and other staples like stiff pudding/dumplings usually cereals/roots/tubers-based (Ene-Obong et al., 2013). Low nutrient availability is also a problem with plant foods. Iron absorption of 2-3\% in whole-grain cereal-legume porridges (Schonfeldt and Hall, 2012), 0.89-3.4\% in fortified whole-cowpea meal 'tubani' (Abizari et al., 2012), and $1.8-4.4 \%$ and $0.9-2.8 \%$ in-vitro available iron and zinc, respectively in unfortified/fortified cereal flours (Towo, Mgoba, Ndossi, \& Kimboka, 2006) were reported. Hemalatha, Platel, \& Srinivasan (2007) found 7-62\% rise in iron bioaccessibility in $24-48 \mathrm{~h}$ sprouted grains, $27-71 \%$ (zinc) and $127-355 \%$ (iron) in fermented raw/cooked 'idli' and 'dosa' batter. Quality flours can enhance the puddings' utilization (Henshaw, McWatters, Oguntunde \& Phillips, 1996; Hillocks et al., 2012). Microbial safety especially of the dishes sold as street food is also crucial and can be achieved through regulatory measures (Wilhelmina et al., 2010; IFPRI, 2017).

\section{Conclusion}

Hunger, malnutrition and poverty are still major challenges in most developing countries like Nigeria, situations linked to decline in agricultural productivity and monotonous diets of starchy staples. Legumes are cheap and major source of protein, vitamins, minerals, and dietary fiber. Nigeria leads in global cowpea production; nevertheless, stagnation characterizes the production with $30 \%$ loss in area between 2006-08 and 2016-18. It, thus, imports to meet domestic demand. In contrast, cowpea production received steady and tremendous positive growth in places like Niger. Cowpea production is constrained by poor yield especially in SSA. Pests, diseases, drought, and poor inputs are major challenges. Adopting improved technologies, favorable policies to improve productivity gains, and diversification can boost pulse production in Nigeria.

Global pulse per capita availability ( $7 \mathrm{~kg} / \mathrm{capita} / \mathrm{year})$ and supply of daily calorie and protein intakes $(2.6$ and $7.7 \%$, respectively) is poor; cereals supply $>50 \%$ calorie and $60 \%$ protein. The availability in Nigeria is $10.6 \mathrm{~kg}$ rising by 2.4 fold since 1985-87. Nevertheless, it is low, cereals being $139 \mathrm{~kg}$ and roots/tubers $(245 \mathrm{~kg})$; cereals supply about 50 and $60 \%$ of the calories and protein, respectively, pulses only 4 and $12 \%$, respectively. Pulse availability is quite higher in places like Rwanda $(35.5 \mathrm{~kg}$ ) and Burundi (41 kg) supplying 38 and $55 \%$ daily protein, respectively.

Pulses are popularly eaten as cooked bean (often with other staples) and steamed/fried pastes in Nigeria. The dishes often lack standardization and can be improved through cereal complementation and optimal processing.

Pulses have huge potentials of improving nutritional security in Nigeria and other places. Their low consumption is a serious hindrance. Boost in productivity/availability, addressing the inherent hard-to-cook and flatulence problems, diverse utilization/innovative products suitable to modern/urban life, and improvement in nutritional quality, safety and acceptability of the local dishes can quite improve their demand/consumption. Tireless efforts towards achieving these should, therefore, be pursued by all stakeholders to curb the prevalent nutritional problems.

\section{Acknowledgement}

The authors are grateful for Trans-disciplinary Training for Resource Efficiency and Climate Change Adaptation in Africa (TRECCAfrica) PhD Scholarship given to first author. The opinions and recommendations in this paper are those of the authors and not TRECCAfrica.

\section{Conflict of Interest}

On behalf of all authors, the corresponding author states that there is no conflict of interest. 


\section{References}

Abate T., Alene, A. D., Bergvinson, D., Shiferaw, B., Silim, S., Orr, A., \& Asfaw, S. (2012). Tropical grain legumes in Africa and South Asia: Knowledge and opportunities. International Crops Research Institute for the Semi-Arid Tropics, Nairobi, Kenya. Retrieved from http://oar.icrisat.org/5680/1/TLL-II_Feb_2012.pdf

Abizari, A.-R., Moretti, D., Schuth, S., Zimmermann, B., Armar-Klemesu, M, \& Brouwer, I. D. (2012). Phytic acid-to-iron molar ratio rather than polyphenol concentration determines iron bioavailability in whole-cowpea meal among young women. J. Nutr., 142, 1950-1955. http://doi.org/10.3945/jn.112.164095

Achi, O. K. (2005). Traditional fermented protein condiments in Nigeria. African Journal of Biotechnology, 4(13), 1612-1621.

Adewale, B. D., \& Odoh, N. C. (2013). A Review on genetic resources, diversity and agronomy of African yam bean: A potential future food crop. Sustainable Agriculture Research, 2(1), 23-43.

Afolabi, W. A. O., Towobola, S. K., Oguntona, C. R. B., \& Olayiwola, I. O. (2013). Pattern of fast foods consumption and contribution to nutrient intake of Nigerian university students. International Journal of Education and Research, 1(5), 1-10.

Agwu, A. E. (2004). Factors influencing adoption of improved cowpea production technologies in Nigeria. Journal of International Agricultural and Extension Education, 11(1), 81-88. https://doi.org/10.5191/jiaee.2004.11109

Ahmad, I. M., \& Kiresur, V. R. (2016). Pulses production in India and Nigeria: Panacea to food security. Research Journal of Agriculture and Forestry Sciences, 4(6), 11-19.

Akah, N. P., \& Onyeka, E. U. (2017). Comparative effects of three levels of insect infestation on selected properties of five Nigerian cowpea varieties. Agro-Science, 16(3), 1-8. https://dx.doi.org/10.4314/as.v16i3.1

Akibode, S., \& Maredia, M. (2011). Global and regional trends in production, trade and consumption of food legume crops. Report submitted to the Standing Panel on Impact Assessment (SPIA) of the CGIAR Science Council, FAO, Rome. Retrieved from https://cas.cgiar.org/sites/default/files/images/Legumetrendsv2.pdf

Akinlua, O., Sedodo, N. S., \& Victoria, A. J. (2013). Glycemic index of selected Nigerian foods for apparently healthy people. Journal of Obesity and Weight Loss Therapy, 3(1), 160-163. https://doi.org/10.4172/2165-7904.1000160

Apata, D. F. (2008). Effect of cooking methods on available and unavailable carbohydrates of some tropical grain legumes. African Journal of Biotechnology, 7(16), 2940-2945.

Aseete, P., Katungi, E., Bonabana-Wabbi, J., Birachi, E., \& Ugen, M. A. (2018). Consumer demand heterogeneity and valuation of value-added pulse products: A case of precooked beans in Uganda. Agric \& Food Secur., 7, 51. https://doi.org/10.1186/s40066-018-0203-3

Asian Productivity Organization. (2003). Report of the APO Seminar on processing and utilization of legumes. Tokyo: Asian Productivity Organization.

Asiwe, J. A. N. (2009). Needs assessment of cowpea production practices, constraints and utilization in South Africa. African Journal of Biotechnology, 8(20), 5383-5388.

Aviara, N. A., Lawal, A. A., Atiku, A. A., \& Haque, M. A. (2013) Bambara groundnut processing, storage and utilization in North-Eastern Nigeria. Continental J. Engineering Sciences, 8(1), 28-36. http://doi.org/10.5707/cjengsci.2013.8.1.28.36

Ayenew, H. Y., Biadgilign, S., Schickramm, L., Abate-Kassa, G., \& Sauer, J. (2018). Production diversification, dietary diversity and consumption seasonality: Panel data evidence from Nigeria. BMC Public Health, 18, 988. http://doi.org/10.1186/s12889-018-5887-6

Azeke, M. A., Fretzdorff, B., Buening-Pfaue, H., Holzapfel, W., \& Betsche, T. (2005). Nutritional value of African yambean: Improvement by lactic acid fermentation. Journal of the Science of Food and Agriculture, 85, 963-970. https://doi.org/10.1002/jsfa.2052

Barimalaa, I. S., Agoha, G., Oboh, C. A., \& Kiin-Kabari, D. B. (2005). Studies on bambara groundnut flour performance in okpa preparation. Journal of the Science of Food and Agriculture, 85, 413-417.

https://doi.org/10.1002/jsfa.1996

Diao, X., Hazell, P., \& Thurlow, J. (2010). The role of agriculture in African development. World Development, 38(10), 1375-1383. https://doi.org/10.1016/j.worlddev.2009.06.011 
Ene-Obong, H. N., \& Obizoba, I. C. (1995). Protein quality of some Nigerian traditional diets based on the African yambean and pigeon pea. Plant Foods for Human Nutrition, 48, 297-309. https://doi.org/10.1007/BF01088489

Ene-Obong, H. N., Sanusi, R. A., Udenta, E. A., Williams, I. O., Anigo, K. M., Chibuzo, E. C., ... Davidson, G. I. (2013). Data collection and assessment of commonly consumed foods and recipes in six geo-political zones in Nigeria: Important for the development of a National Food Composition Database and Dietary Assessment. Food Chemistry, 140, 539-546. https://dx.doi.org/10.1016/j.foodchem.2013.01.102

FAO. (2001). Human energy requirements: Report of a Joint FAO/WHO/UNU expert consultation. Rome: FAO.

FAO. (2012). Sustainable diets and biodiversity, directions and solutions for policy, research and action: Proceedings of the International Scientific Symposium: Biodiversity and sustainable diets united against hunger. Rome: FAO.

FAO. (2016). Pulses: Nutritious seeds for a sustainable future. FAO 2016 International Year of Pulses. Rome: FAO.

FAO. (2017). Regional overview of food security and nutrition in Africa 2016. The challenges of building resilience to shocks and stresses. Accra: FAO.

FAO Statistics. (FAOSTAT). Retrieved from http://faostat.fao.org/

Fasoyiro, S. B., Ajibade, S. R., Omole, A. J., Adeniyan, O. N., \& Farinde, E. O. (2006). Proximate, minerals and antinutritional factors of some underutilized grain legumes in south-western Nigeria. Nutrition and Food Science, 36(1), 18-23. https://doi.org/10.1108/00346650610642151

Fischer, T. A., Byerlee D., \& Edmeades, G. O. (2014). Crop yields and global food security: Will yield increase continue to feed the world? ACIAR Monograph, 158. Canberra: Australian Centre for International Agricultural Research.

Frankenfeld, C. L. \& Wallace, T. C. (2020). Dietary patterns and nutritional status in relation to consumption of chickpeas and hummus in the U.S. population. Appl. Sci., 10, 7341. http://doi.org/10.3390/app10207341

Gerland, P., Raftery, A. E., Ševcíková, H., Li, N., Gu, D., Spoorenberg, T., ... Wilmoth, J. (2014). World population stabilization unlikely this century. Science, 346(6206), 234-237. https://doi.org/10.1126/science.1257469

Hemalatha, S., Platel, K., \& Srinivasan, K. (2007). Influence of germination and fermentation on bioaccessibility of zinc and iron from food grains. European Journal of Clinical Nutrition, 61, 342-348. https://doi.org/10.1038/sj.ejen.1602524

Henshaw, F. O., McWatters, K. H., Oguntunde, A. O., \& Phillips, R. D. 1(996). Pasting properties of cowpea flour: Effects of soaking and decortication method. J. Agric. Food Chem, 44, 1864-1870. https://doi.org/10.1021/jf950698d

Hillocks, R. J., Bennett, C., \& Mponda, O. M. (2012). Bambara nut: A review of utilization, market potential and crop improvement. African Crop Science Journal, 20(1), 1-16.

Hongbété, F., Tidjani, A.-K., \& Kindossi, J. M. (2017). Traditional production technology, consumption and quality attributes of toubani: A ready-to-eat legume food from West Africa. African Journal of Biotechnology, 16(19), 1123-1130. https://doi.org/10.5897/AJB2017.15913

Ifeanyieze, F. O., \& Okeme, I. (2014). Entrepreneurial competency improvement needs of women in agriculture in processing African yam bean seeds for food security in North Central States of Nigeria. International Journal of Research in Applied, Natural and Social sciences, 2(6), 13-22.

International Food Policy Research Institute. (2017). 2017 Global Food Policy Report. Washington, DC: International Food Policy Research Institute. https://doi.org.10.2499/9780896292529

Igbabul, B., Adole, D., \& Sule, S. (2013). Proximate composition, functional and sensory properties of Bambara nut, cassava and soybean flour blends for "akpekpa" production Current Research in Nutrition and Food Science, 1(2), 147-155. https://dx.doi.org/10.12944/CRNFSJ.1.2.06

Kamara, A. Y., Tofa, A. I., Kyei-Boahen, S., Solomon, R., Ajeigbe, H. A., \& Kamai, N. (2016). Effects of plant density on the performance of cowpea in Nigerian Savannas. http://doi.org/10.1017/S0014479716000715

KIu, G. Y. P., Amoatey, H. M., Bansa, D., \& Kumaga, F. K. (2001). Cultivation and use of African yam bean in the Volta Region of Ghana. The Journal of Food Technology in Africa, 6, 74-77. 
Kormawa, P. M., Chianu, J. N., \& Manyong, V. M. (2000). Cowpea demand and supply patterns in West Africa: The case of Nigeria. Paper presented at the World Cowpea Conference III, Ibadan, Nigeria. Retrieved from https://www.researchgate.net/profile/Jonas_Chianu/publication/237536245_Cowpea_demand_and_supply_ patterns_in_West_Africa_the_case_of_Nigeria/links/0f31752dfd30154d1b000000.pdf

Langyintuoa, A. S., Lowenberg-DeBoer, J., Faye, M., Lambert, D., Ibro, G., Moussa, B., ... Ntoukam, G. (2003). Cowpea supply and demand in West and Central Africa. Field Crops Research, 82, 215-231. https://doi.org/0.1016/S0378-4290(03)00039-X

Lawal, W. A. (2011). An analysis of government spending on agricultural sector and its contribution to GDP in Nigeria. International Journal of Business and Social Science, 2(20), 244-250.

Madukwe, E. U., \& Ene-Obong, H. N. (2002). Adequacy of micronutrient content of south eastern Nigerian meals in meeting the nutritional needs of vulnerable groups. Agro-Science, 3(2), 1-9. https://doi.org/10.4314/as.v3i2.1511

Muchero. W., Ehlers, J. D., \& Roberts, P. A. (2010). QTL analysis for resistance to foliar damage caused by Thrips tabaci and Frankliniella schultzei (Thysanoptera: Thripidae) feeding in cowpea. Molecular Breeding, 25(1), 47-56. http://doi.org/10.1007/s11032-009-9307-6

Nnam, N. M. (1997). Chemical and sensory evaluation of vegetable milks from African yam bean and maize. Plant Foods for Human Nutrition, 51, 265-275. https://doi.org/10.1023/A:1007918011504

Nnamani, C. V., Ajayi, S. A., Oselebe, H. O., Atkinson, C. J., Igboabuchi, A. N., \& Ezigbo, E. C. (2017). Sphenostylis stenocarpa (ex. A. Rich.) Harms., a fading genetic resource in a changing climate: Prerequisite for conservation and sustainability. Plants, 6(30), 1-16. https://doi.org/10.3390/plants6030030

Obiakor-Okeke, P. N. (2014). Comparative evaluation of chemical and functional properties of some lima bean varieties consumed in Arondizuogu, Imo State, Nigeria. Journal of Food and Nutrition sciences, 2(4), 168-172. https://doi.org/10.11648/j.jfns.20140204.21

OECD/FAO. (2016). OECD-FAO Agricultural Outlook 2016-2025. Paris: OECD. http://dx.doi.org/10.1787/agr_outlook-2016-En

Ogban, P. I., Ogunewe, W. N., Dike, R. I., Ajaelo, A. C., Ikeata, N. I., Achumba, U. E., \& Nyong, E. E. (2008). Effect of tillage and mulching practices on soil properties and growth and yield of cowpea in Southeastern Nigeria. Agro-Science, 7(2), 118-128. https://doi.org/10.4314/as.v7i2.1593

Ogbonna, D. N., Sokari, T. G., \& Achinewhu, S. C. (2001). Development of an owoh-type product from African yam beans seeds by solid substrate fermentation. Plant Foods for Human Nutrition, 56, 183-194. https://doi.org/10.1023/A:1011185513717

Ojo, E. O., \& Adebayo, P. F. (2012). Food security in Nigeria: An overview. European Journal of Sustainable Development, 1(2), 199-220. https://doi.org/10.14207/ejsd.2012.v1n2p199

Okeke, E. C., Eneobong, H. N., Uzuegunam, A. O., Ozioko, A. O., \& Kuhnlein, H. (2008). Igbo traditional food system: Documentation, uses and research needs. Pakistan Journal of Nutrition, 7(2), 365-376. https://doi.org/10.3923/pjn.2008.365.376

Okeke, E. C., Eneobong, H. N., Uzuegbunam, A. O., Ozioko, A. O., Umeh, S. I., \& Kuhnlein, H. (2009). Nutrient composition of traditional foods and their contribution to energy and nutrient intakes of children and women in rural households in Igbo culture area. Pakistan Journal of Nutrition, 8(4), 304-312. https://doi.org/10.3923/pjn.2009.304.312

Okuneye, P. A. (2002). Rising cost of food prices and food insecurity in Nigeria and its implication for poverty reduction. CBN Economic and Financial Review, 39(4). Retrieved from https://www.cbn.gov.ng/OUT/PUBLICATIONS/EFR/RD/2002/efrVol39-4-6.pdf

Onimawo I. A., Ijeh, I., Ukoha, U., \& Nwachukwu, G. T. (2007). Determination of the glycemic index of steamed cakes using two different legumes 'Bambara nut and cowpea'. African Journal of Biochemistry Research, 1(7), 142-147.

Oranusi, U. S., \& Braide, W. (2012). A study of microbial safety of ready-to-eat foods vended on highways: Onitsha-Owerri, south-east Nigeria. International Research Journal of Microbiology, 3(2), 66-71.

Oriola, E. O. (2009). Framework for food security and poverty reduction in Nigeria. European Journal of Social Sciences, 8(1), 132-139. 
Palmer, S. M., Winham, D. M., Oberhauser, A. M., \& Litchfield, R. E. (2018). Socio-ecological barriers to dry grain pulse consumption among low-income women: A mixed methods approach. Nutrients, 10, 1108. http://doi.org/10.3390/nu10081108

Rackis, J. J., Sessa, D. J., \& Honig, D. H. (1979). Flavor problems of vegetable proteins. J. Am.Oil Chemists' Soc., 56, 262-271. https://doi.org/10.1007/BF02671470

Sanon, A., Ba, N. M., Binso-Dabire, C. L., \& Pittendrigh, B. R. (2010). Effectiveness of spinosad (naturalytes) in controlling the cowpea storage pest, Callosobruchus maculatus (Coleoptera: Bruchidae). Journal of Economic Entomology, 103(1), 203-210. http://doi.org/10.1603/EC09093

Schneider, A. V. C (2002). Overview of the market and consumption of pulses in Europe. British Journal of Nutrition, 88(Suppl. 3), S243-S250. http://doi.org/10.1079/BJN2002713

Schonfeldt, H. C., \& Hall, N. G. (2012). Dietary protein quality and malnutrition in Africa. British Journal of Nutrition, 108, S69-S76. https://doi.org/10.1017/S0007114512002553

Szczebyło, A., Rejman, K., Halicka, E., \& Laskowski, W. (2020). Towards more sustainable diets-Attitudes, opportunities and barriers to fostering pulse consumption in Polish cities. Nutrients, 12, 1589. http://doi.org/10.3390/nu12061589

Steyn, N. P., Mchiza, Z., Hill, J., Davids, Y. D., Venter, I., Hinrichsen, E., ... Jacobs, P. (2013). Nutritional contribution of street foods to the diet of people in developing countries: A systematic review. Public Health Nutrition, 17(6), 1363-1374. http://doi.org/10.1017/S1368980013001158

Tijjani, A. R., Nabinta, R. T., \& Muntaka, M. (2015). Adoption of innovative cowpea production practices in a rural area of Katsina State, Nigeria. J. Agric. Crop Res., 3(4), 53-58.

Timko, M. P., Ehlers, J. D., \& Roberts, P. A. (2007). Cowpea. In C. Kole (Eds.), Genome mapping and molecular breeding in plants: Pulses, sugar and tuber crops (pp. 49-67). Springer-Verlag Berlin Heidelberg. https://doi.org/10.1007/978-3-540-34516-9_3

Towo, E., Mgoba, C., Ndossi, G. D., \& Kimboka, S. (2006). Effect of phytate and iron-binding phenolics on the content and availability of iron and zinc in micronutrients fortified cereal flours. African Journal of Food, Agriculture, Nutrition and Development, 6(2), 1-14. https://doi.org/10.4314/ajfand.v6i2.71756

Udenta, E. A., Obizoba, I. C., \& Oguntibeju, O. O. (2014). Anti-diabetic effects of Nigerian indigenous plant foods/diets. Antioxidant-antidiabetic agents and human health. http://dx.doi.org/10.5772/57240

Uebersax, M. A., Ruengsakulrach, S., \& Occena, L. G. (1991). Strategies and procedures for processing dry beans. Food Technology, 45(9), 104-111.

Uebersax, M. A. (2006). Dry edible beans: Indigenous staple and healthy cuisine. Forum on Public Policy: A Journal of the Oxford Round Table. Retrieved from https://forumonpublicpolicy.com/archive06/uebersax.pdf

UNSD. (2006). Note on definition of regions for statistical analysis. Retrieved from https://doi.org/SA-2006-15-Grouping-USND.pdf

Uvere, P. O., Uwaegbute, A. C., \& Adedeji, E. M. (1999). Effects of malting on the milling performance and acceptability of Bambara groundnut (Voandzeia subterranean Thouars) seeds and products. Plant Foods for Human Nutrition, 54, 49-57. https://doi.org/10.1023/A:1008177221438

von Grebmer, K., Bernstein, J., Wiemers, M., Acheampong, K., Hanano, A., Higgins, B., ... Fritschel, H. (2020). Global hunger index one decade to zero hunger linking health and sustainable food systems. Dublin/Bonn: Chatham House. Retrieved from https://www.globalhungerindex.org/pdf/en/2020.pdf

Wilhelmina, Q., Jongerden, J., Essegbey, G., \& Ruivenkamp G. (2010). Globalization vs. localization: Global food challenges and local solutions. International Journal of Consumer Studies, 34, 357-366. http://doi.org/10.1111/j.1470-6431.2010.00868.x

Wokoma, E. C., \& Aziagba, G. C. (2001). Sensory evaluation of 'dawadawa' produced by the traditional fermentation of African yam bean seeds. Journal of Applied Science and Environmental Management, 5(1), 85-91. https://doi.org/10.4314/jasem.v5i1.54961

Yellavila, S. B., Agbenorhevi, J. K., Asibuo, J. Y., \& Sampson, G. O. (2015). Proximate composition, minerals content and functional properties of five Lima bean accessions. Journal of Food Security, 3(3), 69-74.

http://doi.org/10.12691/jfs-3-3-1 


\section{Copyrights}

Copyright for this article is retained by the author(s), with first publication rights granted to the journal.

This is an open-access article distributed under the terms and conditions of the Creative Commons Attribution license (http://creativecommons.org/licenses/by/3.0/). 